International Business and Global Economy 2018, no. 37, pp. 41-52

Biznes międzynarodowy w gospodarce globalnej 2018, nr 37, s. 41-52

Edited by the Institute of International Business, University of Gdańsk

ISSN 2300-6102

e-ISSN 2353-9496

DOI 10.4467/23539496IB.18.003.9376

Robert Ciborowski

Uniwersytet w Białymstoku

\title{
Determinanty międzynarodowego transferu technologii (MTT) w krajach słabo rozwiniętych
}

Celem artykułu jest ocena warunków międzynarodowego transferu technologii w gospodarkach słabo rozwiniętych oraz możliwości jego zdynamizowania przez wykorzystanie odpowiednich czynników instytucjonalnych. Osiągnięcie tego celu wymagało krytycznej analizy literatury przedmiotu i szeregu badań dotyczących krajów słabo rozwiniętych. Przeprowadzona ocena wykazała, że zdolność przedsiębiorstw do transferu technologii jest jednym ze wskaźników innowacyjności w aspekcie szybszego procesu konwergencji technologicznej. Tym samym szczególnego znaczenia nabiera tworzenie i wykorzystanie warunków do transferu technologii poprzez wzrost nakładów na $B+R$, rozwój infrastruktury instytucjonalnej oraz tworzenie sieci współpracy obejmującej międzynarodowe podmioty gospodarcze. Zaniechanie tego typu działań, zwłaszcza w dobie coraz większej otwartości i liberalizacji gospodarczej, może spowolnić zmniejszanie dystansu rozwojowego krajów słabo rozwiniętych.

Słowa kluczowe: transfer technologii, rozwój gospodarczy, innowacyjność

Klasyfikacja JEL: O11, O32, F63

\section{International technology transfer (ITT) determinants in low-developed countries}

The aim of the paper is to assess the conditions of international technology transfer in lowdeveloped economies and the possibility of its dynamism through the use of appropriate institutional factors. The implementation of this objective required critical analysis of the subject literature and a number of studies carried out in low-developed countries. The conducted assessment indicated that the ability of enterprises to transfer technology is one of the indicators of innovation in the aspect of a faster process of technological convergence. Thus, the creation and use of conditions for technology transfer is of special importance through the increase in R\&D outlays, the development of institutional infrastructure, and the creation of cooperation networks including international economic entities. Abandoning this type of activities, especially in the era of increasing openness and economic liberalization, may slow down the reduction in the development gap of the low-developed countries.

Keywords: technology transfer, economic development, innovativeness

JEL classification: O11, O32, F63 


\section{Przedmiot międzynarodowego transferu technologii}

Międzynarodowy transfer technologii (MTT) stanowi skutek różnego typu powiązań gospodarczych o charakterze międzynarodowym i ściśle wiąże się z dyfuzją innowacji w skali gospodarki światowej [Ciborowski, 2016, s. 128]. „Międzynarodowy transfer technologii zachodzi w każdym przypadku, gdy wiedza techniczna staje się dostępna w kraju w inny sposób niż w wyniku własnych prac badawczych czy też gromadzenia doświadczenia" [Misala, 2003, s. 198]. Transfer ten wynika zatem z rozwiniętej współpracy międzynarodowej lub zakupu rozwiązań technologicznych za granicą.

Biorąc pod uwagę przebieg kolejnych etapów transferu, międzynarodowy transfer technologii możemy podzielić na kilka faz [Mansfield, 1995, s. 87-88]:

- materiałową - eksport nowych materiałów lub produktów;

- projektową - zawierająca parametry pozwalające na wytwarzanie danego typu produktów;

- transferu zdolności produkcyjnych, niezbędnych do adaptacji nowych technologii i uruchomienia procesu wytwórczego;

- nauczania, czyli przystosowanie nowych technologii do warunków lokalnych. W krajach słabo rozwiniętych MTT dotyczy początkowo technologii "twardych", by w późniejszych etapach ewoluować w stronę rozwiązań "miękkich" wiedzy i informacji [Souder, Nashar, 1990, s. 5-16]. Tym samym technologia, której transfer dotyczy, może przybierać różnorakie formy w zależności od etapu rozwoju, na którym znajduje się dana gospodarka, w najbardziej rozwiniętej formie ma jednak charakter informacji lub wiedzy. Tego typu rozróżnienie jest istotne z punktu widzenia ponoszonych kosztów oraz efektywnej alokacji przyszłych innowacji, które powstawać będą $\mathrm{w}$ warunkach niepewności i znacznego ryzyka [Arrow, 1962, s. 609-611].

Oba podejścia (informacja i wiedza) mogą występować w tym samym zakresie jako dwa odrębne elementy lub na siebie zachodząc. Współwystępowanie obu skutkuje koniecznością uwzględniania ich w modelach dotyczących transferu technologii. Ponadto różnice $w$ przedmiocie transferu będą miały swoje odzwierciedlenie w analizie poszczególnych związków i relacji [Osman-Gani, 1999, s. 9-18].

Czynniki wpływające na umiędzynarodowienie transferu technologii są zmienne w czasie. Ponadto dane statystyczne [Weresa, 2012, s. 163-189] sugerują, że wyraźnie rośnie znaczenie czynników podażowych, co będzie powodować ograniczanie dostępności wysoko kwalifikowanych pracowników w sektorze badawczo-rozwojowym oraz personelu technicznego. Jest to równoznaczne ze spadkiem znaczenia czynników popytowych, co bezpośrednio wynika z "globalizacji przepływu produktów" i zmniejszenia możliwości adaptacji nowych tech- 
nologicznie produktów w ramach rynków lokalnych [Bozeman, 2000, s. 627-655; Hoekman, Maskus, Saggi, 2005, s. 1588-1602].

Międzynarodowy transfer technologii jest jedną z dróg dojścia do innowacji technicznych i wyższej konkurencyjności. Importowana technologia może wywierać bezpośredni wpływ na rozwój gospodarczy kraju-importera na trzy, częściowo związane ze sobą, sposoby [UNIDO, 2003, s. 14-15]:

- transfer technologii może zwiększyć fizyczne zasoby dostępnych czynników produkcyjnych;

- zagraniczne technologie mogą przyczynić się do wzrostu gospodarczego poprzez wykorzystanie istniejących zasobów;

- transfer zagranicznej technologii może spowodować znaczący wzrost wydajności istniejących czynników.

Celem długookresowym powinno być wpływanie na strukturalne zmiany technologiczne i zmniejszanie dystansu rozwojowego w stosunku do krajów wysoko rozwiniętych. Dlatego też MTT powinien stanowić punkt wyjścia do tworzenia własnych rozwiązań i wzrostu innowacyjności.

Na tej podstawie można wskazać dwie trajektorie technologiczne charakterystyczne dla krajów wysoko i słabo rozwiniętych [Utterback, 1994, s. 36-48].

W warunkach pierwszej z nich w krajach wysoko rozwiniętych firmy z nowymi technologiami rozszerzają płynnie zakres innowacji. Sektor, który technologię pozyskał, dojrzewa, a konkurencja cenowa firm staje się bardziej intensywna. W celu usprawnienia działalności firmy zwiększają zainteresowanie $B+R$ i poszukują możliwości innowacji radykalnych. Dzięki temu niektóre z nich uzyskują przewagę konkurencyjną, jednak coraz bardziej dynamiczna rywalizacja spowoduje poszukiwanie możliwości lokowania swojej działalności poza granicami kraju.

Nieco inaczej wygląda sytuacja w gospodarkach słabiej rozwiniętych, w których trajektoria technologiczna przechodzi trzy fazy: nabycia, asymilacji i ulepszenia. Firmy pozyskują technologie z zagranicy, dzięki czemu mogą rozwijać posiadany potencjał produkcyjny (standardowy, mało wyspecjalizowany). Technologia będzie się rozprzestrzeniać, wzrośnie konkurencja, która z kolei wzmoże zainteresowanie nowymi rynkami. Pojawi się dodatkowy personel ulepszający technologię. Powstaną nowe linie technologiczne oparte na własnych $B+R$, co zwiększy konkurencyjność technologiczną i eksport.

Zagraniczne technologie są jednym z głównych czynników rozwoju potencjału gospodarczego krajów słabo rozwiniętych poprzez inwestycje, technologie i kanały marketingowe, stopniowe wchłanianie i adaptowanie importowanej wiedzy oraz rozwój kwalifikacji. Bezpośrednie inwestycje zagraniczne (BIZ), wspólne przedsięwzięcia, umowy licencyjne i z producentami oryginalnego wyposażenia oraz podobne transakcje odegrały instrumentalną rolę w osiągnięciu sukcesu przemysłowego przez niektóre kraje słabo rozwinięte. Import technolo- 
gii był tam w dużej mierze wykorzystywany jako środek edukacji i punkt wyjścia do dalszych innowacji.

Międzynarodowy transfer technologii może odgrywać podobną rolę we wzmacnianiu rozwoju gospodarczego krajów rozwijających się poprzez zwiększanie ich konkurencyjności na rynkach międzynarodowych, jeśli wykorzystuje się go do edukacji i jeśli jest skoordynowany z rozwojem krajowych technologii. Może się to odbywać według różnorakich modeli odzwierciedlających tzw. łańcuch rozwoju technologii [Ramanathan, 2001].

Do każdego z tych podejść przypisane są odpowiednie mechanizmy, będące sposobami pozyskania technologii, definiowane jako kanały transferu.

W każdym przypadku czynnikiem transferu jest dostępność technologii i wiedzy. Jeżeli jedne podmioty posiadają technologię i wiedzę, a drugie ich potrzebują, to zawsze może dojść do różnych form przenoszenia czy komercjalizowania.

Transfer technologii możliwy jest $\mathrm{w}$ dużym stopniu dzięki powiązaniom korporacyjnym, takim jak: franchising, podwykonawstwo, projekty pod klucz, kontrakty menedżerskie czy alianse strategiczne [Jindra, 2006]. Również Dominique Foray zwraca uwagę na wzrost znaczenia innowacji opartych na współpracy między firmami, w formie joint ventures, umów i outsourcingu [Foray, 2007]. Kanał inwestycyjny jest szczególnie istotny ze względu na silną zdolność generowania efektów zewnętrznych (spillovers).

\section{Przebieg procesów międzynarodowego transferu technologii w krajach słabo rozwiniętych}

Kombinacja wykorzystywanych kanałów transferu zmienia się w czasie. Wraz z postępami w zakresie kształcenia i rozwoju technologicznego otwierają się nowe perspektywy, gdyż potencjał absorpcyjny krajów słabo rozwiniętych umożliwia im coraz lepszy wybór i adaptację nowych technologii. Doświadczenie pokazuje jednak, że w ostatnich latach nawet szybko rozwijającym się gospodarkom coraz trudniej dorównać najlepszym, gdyż zbliżają się do technologicznej granicy w rozwijanych tam dziedzinach. Dlatego powinny one podlegać różnym formom MTT w coraz szerszym zakresie i opierać się na skutecznym pozyskiwaniu kapitału technologicznego.

Można wyróżnić kilka ścieżek dostępu do kapitału wydatkowanego na technologie.

Po pierwsze, bezpośrednie inwestycje zagraniczne, pozwalające na pozyskiwanie technologii oraz wykorzystanie istniejących modeli ich wdrażania czy wykorzystania [Ozawa, 1992, s. 27-54]. Kluczowe korzyści to zmiana charakteru produkcji na bardziej nowoczesny oraz rozwój sektorów o wyższym poziomie 
technologicznym. Jest to najczęściej wykorzystywany kanał w krajach słabo rozwiniętych, ze względu na możliwość dostępu do technologii już sprawdzonych oraz uzyskanie większej ilości kapitału zagranicznego.

Po drugie, przedsiębiorstwa poprzez współpracę międzynarodową pozyskują kapitał na zwiększenie wydatków na $B+R$, powodując wzrost intensywności technologicznej (szerszego zakresu rozwoju technologii) i zaawansowania technologicznego produkcji [Hobday, 1995, s. 72-80]. W krajach słabo rozwiniętych wymaga to stworzenia wewnętrznych warunków działalności B+R, głównie w kontekście wyższej jakości kapitału ludzkiego. Jest to proces rozciągnięty w czasie i kosztowny, stanowiący najczęściej konsekwencję przekształcania już pozyskanych rozwiązań $B+R$.

Po trzecie, powiązania międzynarodowe (alianse, fuzje, przejęcia) pozwalają rozszerzyć zakres stosowanych nowych technologii na większą liczbę branż czy sektorów. W krajach słabo rozwiniętych akumulacja środków i możliwości w branżach mniej rozwiniętych technologicznie w dłuższym okresie skłania przedsiębiorstwa do poszukiwania innych, bardziej innowacyjnych form czy zakresów działalności (od przemysłu przetwórczego do opartego na B+R) [Gu, Steinmueller, 1996, s. 2-3].

Przejęcia firm i strategiczne partnerstwa wymagają, by firmy w krajach rozwijających się były zdolne do podjęcia współpracy międzynarodowej. Mogą być one sposobem na osiągnięcie trzech celów: pozyskania technologii, wejścia na dynamiczne rynki zaawansowanych produktów i utrzymania zmian technologicznych. Wiąże się z tym jednak konieczność posiadania znaczących zasobów, nie tylko finansowych, ale i technologicznych. Aby zawrzeć strategiczne partnerstwo, przedsiębiorstwa muszą posiadać odpowiednie aktywa. Jeśli cel stanowi podjęcie wspólnych działań rozwojowych w sferze technologii, niezbędne jest istnienie dużego potencjału technologicznego. Pozostaje to jednak poza zasięgiem większości firm w krajach rozwijających się. Technologiczne partnerstwa dotyczą tylko najbardziej dynamicznych podmiotów w gospodarkach, które osiągnęły nieco wyższy od przeciętnego poziom rozwoju technologicznego.

W krótkim okresie firmy w krajach rozwijających się mogą uciekać się do naśladownictwa, bo ich przewagą są niższe płace. Proste naśladownictwo nie wystarczy jednak do osiągnięcia trwałej przewagi konkurencyjnej. Musi ono posiadać elementy "twórcze”. Poza tym, samo naśladownictwo wcale nie jest łatwe i wymaga sporych zasobów wiedzy, czyli przygotowania do pozyskiwania i przekształcania technologii.

MTT musi posiadać odpowiednie zaplecze finansowe na każdym etapie jego trwania, aby tworzyć pozycję technologiczną gospodarki. Źródła finansowania mogą być różne: komercyjne (kredyty, środki własne firm), publiczne czy typu venture. Biorąc pod uwagę możliwości pozyskiwania środków, ich koszty oraz 
skuteczność wydatkowania, wydaje się, że czynnikiem stymulującym powinno być ułatwienie dostępu do finansowania typu venture capital, państwowych gwarancji bankowych czy kredytów technologicznych.

Edwin Mansfield twierdzi, że pozycję technologiczną kraju wyznaczają również m.in. takie czynniki, jak: klimat społeczny, system edukacji, środowisko naukowe, ilość i jakość badań przemysłowych, charakter rynku krajowego czy jakość kadr kierowniczych [Mansfield, 2002, s. 362]. Efektywność MTT jest uwarunkowana też m.in.: rozumieniem technologii, aktywnością technologiczną, kanałami komunikacyjnymi, czynnikami wpływającymi na wielkość transferu, modelami transferu technologii [Jun-Choi, 2009, s. 49], a także kosztami umów o TT czy problemami związanymi z dostawcami dóbr inwestycyjnych [Shashikant, Khor, 2013, s. 2-4]. Jednak w całym procesie występuje szereg barier.

Są one $w$ dużej mierze następstwem barier transferu wewnętrznego, zachodzącego pomiędzy krajowymi jednostkami badawczymi a przedsiębiorstwa$\mathrm{mi}$, do których zaliczyć można: niedostosowanie sektora nauki do potrzeb rynku i przemysłu, niski poziom wydatków na $\mathrm{B}+\mathrm{R}$ i szkolnictwo, nierozwinięty system pośrednictwa transferu technologii oraz słabość ustawodawstwa. Zauważyć należy, że najwyższy stopień zintegrowania działalności $B+R$ i produkcji obserwuje się w firmach innowacyjnych należących do sektora high-tech, o wysokim stopniu specjalizacji [Poznańska, 2001, s. 25-26].

Współpraca innowacyjna między krajami jest najefektywniejsza w sytuacji niedużej różnicy potencjałów technologicznych. Proces adaptacji technologii $\mathrm{w}$ różnych warunkach przebiega w zmiennym tempie i z różną intensywnością, w zależności od zdolności adaptacyjnych. Zbalansowany model transferu dowodzi, że aby był on efektywny, firmy, między którymi zachodzi proces transferu, powinny wykazywać podobieństwa w zakresie uwarunkowań gospodarczych i prawnych, organizacji pracy i poziomu technologicznego [Steenhuis, de Bruijn, 2005]. MTT nie jest efektywny w warunkach zbyt dużej rozbieżności między rozwojem gospodarczym kraju transferującego i adaptującego technologie. Zauważyć jednocześnie należy, że tylko transfer z krajów rozwiniętych, dysponujących najnowszymi technologiami, pozwolić może na względnie szybkie zmniejszenie luki technologicznej [Keller, 1999].

\section{Rola międzynarodowego transferu technologii w konwergencji technologicznej}

Obecnie problematyka MTT dotyczy w głównej mierze możliwości wykorzystania technologii importowanych i przekształcenia ich w dynamiczny czynnik wzrostu innowacyjności przedsiębiorstw krajowych. Możliwości innowacyjne 
ucieleśniane są w zasobach firm i stanowią główny czynnik przyspieszania rozwoju gospodarczego.

Przedsiębiorstwa, które przyjmują aktywne strategie rozwoju technologicznego, mają ogromne znaczenie gospodarcze wynikające z największych zdolności do generowania nadwyżek finansowych i pozwalają na tworzenie lepszych warunków transformacji pozyskiwanych technologii w nowe produkty czy procesy. Akumulacja możliwości technologicznych firm stanowi główny aspekt konwergencji technologicznej krajów słabo rozwiniętych.

Istotnym zagadnieniem związanym z konwergencją technologiczną staje się również określenie stabilności systemów regulacyjnych i instytucji narodowych w warunkach rosnącej siły konkurencyjnej [Boyer, Drache, 1996, s. 48-50] oraz odpowiedź na pytanie, czy różnice instytucjonalne między gospodarkami są na tyle silne, że procesy deregulacyjne wsparte integracją międzynarodową nie wywołają procesu tworzenia jednego, podobnego modelu gospodarczego.

Szereg badań dotyczących wzrostu gospodarczego w gospodarce światowej potwierdza, że proces technicznego catch-up nie jest autonomiczny, ale zależy od inwestycji w edukację, wiedzę oraz działalność B+R. Czynniki te stały się podstawą sukcesu krajów rozwijających się w zmniejszaniu luki technologicznej, jednak nie we wszystkich. Wynika to z braku automatyzmu i stabilności w międzynarodowej dyfuzji innowacji [Bell, Pavitt, 1993, s. 168-170]. W krajach słabo rozwiniętych poziom wydatków na $B+R$ jest stosunkowo niski i w najbliższych latach raczej nie ulegnie wzrostowi. Dlatego znaczna część działalności $B+R$ musi być wspierana wydatkami publicznymi, będącymi konsekwencją polityki ekonomicz-nej. Państwo powinno również tworzyć warunki do akumulacji kapitału, co pozwoli w dłuższym okresie zwiększyć możliwości inwestycyjne firm.

Konwergencja technologiczna w krajach rozwijających się przebiega bardziej spontanicznie i niejednostajnie, natomiast w krajach wysoko rozwiniętych stanowi proces łagodniejszy, gdyż ich wewnętrzne systemy gospodarcze (przede wszystkim polityka ekonomiczna) są lepiej przygotowane do globalizacji technicznej [Nelson, 1991, s. 121]. MTT wymaga wykorzystania instrumentów polityki ekonomicznej liberalizujących dostęp do nowych rozwiązań oraz zmniejszenia kosztów ich pozyskiwania, głównie fiskalnych. Ponadto rząd powinien prowadzić odpowiednią politykę strukturalną, zapewniającą dopływ technologii najbardziej korzystnych z punktu widzenia makroekonomicznego.

Zmiana paradygmatu polityki przemysłowej wymaga obecnie ukierunkowania na międzynarodowe przepływy wiedzy, informacji czy technologii. System instytucji państwa powinien koordynować priorytety krajowej i zagranicznej działalności technologicznej poprzez ograniczenie podejścia makro i skupienie się na bezpośrednich ocenach możliwości innowacyjnych przedsiębiorstw. Polityka przemysłowa to dziś zmniejszenie bezpośredniej roli państwa przy jednoczesnym wzroście roli firm w kontekście ich szerszej współpracy międzynarodowej. 
Różnice w sposobie i intensywności transferu technologii związane są również z rodzajem funkcjonującego systemu gospodarczego. Biorąc pod uwagę system liberalny i etatystyczny, można wskazać na szereg czynników, które przez swoją specyfikę uwidaczniają różnorodność tego procesu. Najważniejsze z nich to: system pieniężny i fiskalny, rynek pracy, rynek technologii, stopień otwartości oraz układ instytucjonalny gospodarki. W krajach słabo rozwiniętych, liberalizujących się, zakres MTT jest szerszy i trafia do nich bardziej zaawansowana technologia. Jest to wynik większego udziału firm w bezpośrednim procesie przepływu technologii.

Liberalizacja i globalizacja rynków redukuje ograniczenia dostępu do wiedzy oraz do importu technologii. Ponadto umożliwia większą liczbę różnorodnych powiązań między narodowymi systemami innowacyjnymi. Dzięki temu zmienia się układ strukturalny i instytucjonalny w stronę lepszego dostosowania do warunków gospodarki światowej.

Przedsiębiorstwa w gospodarkach „opóźnionych technologicznie” ograniczane są przez liczne „negatywne efekty zewnętrzne” czy „negatywne czynniki pozacenowe" (brak odpowiednich dostawców, nieprzewidywalność prawa, ograniczone źródła finansowania, gorsza infrastruktura techniczna). Poszczególne firmy muszą kompensować te utrudnienia poprzez związki (współpracę) z innymi firmami [Radosevic, 1999, s. 25]. Zakres joint ventures w krajach słabo rozwiniętych powinien się rozszerzać, zarówno z uwagi na dostęp do nowych rozwiązań, jak i konieczność pozyskania wiedzy i umiejętności niezbędnych do rozwoju technologii. Szczególnie etap początkowego rozwoju technologicznego wymaga współpracy z firmami doświadczonymi i silnymi kapitałowo.

Proces kompensacji działań pozwalających na ograniczenie oddziaływania czynników negatywnych odbywa się poprzez tworzenie powiązań sieciowych (konglomeraty, klastry), różne formy współpracy krajowej i zagranicznej (joint ventures, alianse) oraz lepsze wykorzystanie istniejących powiązań finansowych czy infrastrukturalnych. W krajach rozwijających się procesy tego typu występują bardzo rzadko, a przedsiębiorstwa korzystają raczej z wewnętrznych możliwości rozwoju (współpraca właścicielska między firmami), natomiast w krajach azjatyckich procesy kompensacji są bardziej intensywne [Stark, 1996, s. 993-1027].

Tempo procesu kompensacji wiąże się z intensywnością pozyskiwania nowej wiedzy przez firmy krajowe oraz intensywnością pozyskiwania kapitału na nowe technologie z zagranicy. Miernikiem oceny procesu MTT będzie zatem tempo przyswajania nowych rozwiązań przez przedsiębiorstwa przyjmujące technologie. Proces ten przyspiesza w krajach rozwijających się, o dużych zasobach kapitałowych (np. Chiny czy Indie), w pozostałych tempo nie jest zbyt wysokie (np. Polska).

Przebieg tego typu procesów musi być ściśle związany z rozwojem zasobów ludzkich (wiedza, doświadczenie, umiejętności), ze względu na konieczną komp- 
lementarność z zasobami kapitałowymi oraz podążanie w stronę większego udziału przedsiębiorstw w działalności B+R.

Jeden z kluczowych elementów oceny MTT stanowi wyjaśnienie sposobów, możliwości i charakteru przepływu wiedzy i technologii między firmami z różnych krajów. Pomimo szacunków ogólnych skalę procesu transferu technologii trudno jednak zmierzyć i skwantyfikować, co stwarza kłopoty analityczne. Wrażliwa natura tego typu transakcji odzwierciedla transfer cen i zysków oraz stanowi element całości systemu gospodarczego, co bardzo często bywa niedostrzegane.

Proces zwiększania efektywności transferu technologii, a przez to dynamizowania konwergencji gospodarczej, jest nieciągły. Przedsiębiorstwa uczestniczące w tym procesie muszą przejść szereg faz charakteryzujących się specyficzną wiedzą i wymaganiami. Zmiany w charakterze wiedzy i mechanizmach dostępu do technologii rozpoczynają się od prostej konkurencji cenowej poprzez podwykonawstwo aż do aliansów technologicznych. Trwa to do momentu, aż firmy krajowe nie wprowadzą do swojej działalności ulepszonych strategii w zakresie organizacji, finansów czy technologii.

Tempo transferu technologii będzie przyspieszać, gdy przedsiębiorstwa transnarodowe (KTN) zwiększą przepływ technologii „miękkich” (opartych na wiedzy), co wpłynie pozytywnie na wzrost przewag konkurencyjnych w aspekcie wykorzystania nieucieleśnionych technologii. Możliwości absorpcyjne filii zagranicznych muszą być wzmacniane w celu stworzenia szans na rozwój otrzymywanych technologii. Aby zwiększyć swój potencjał badawczy i uzyskać korzyści innowacyjne, firmy muszą odchodzić od transferu istniejących technologii w stronę transferu wiedzy i podnoszenia kwalifikacji.

Istotą transferu technologii jest dziś uzyskanie jak najwyższego poziomu efektywności $\mathrm{z}$ uczestnictwa $\mathrm{w}$ ogólnoświatowych procesach produkcyjnych. Powiązania międzynarodowe firm stwarzają warunki do wzrostu krajowych (lokalnych) zdolności technologicznych, dostępu do nowych odbiorców czy dostawców, wzrostu jakości produkcji i w końcu do wyższej konkurencyjności.

Procesy konwergencji wymagają w tym ujęciu większego zakresu powiązań sieciowych czy międzynarodowych w celu uzyskania lepszego miejsca w łańcuchu wartości.

Integracja technologiczna, szeroka współpraca oraz dynamika uczenia się nie gwarantują przedsiębiorstwom zmniejszania dystansu technologicznego. Transfer technologii i jego wpływ na konwergencję zależeć będzie w dużej mierze od regionalnej i krajowej pozycji innowacyjnej firm, a także ich skłonności do przyswajania nowych rozwiązań. Poszczególne elementy powinny tworzyć kompleksową strategię technologiczną oraz zwiększać efektywność realizacji poszczególnych etapów rozwoju technologicznego gospodarki narodowej.

Jest to dla krajów słabo rozwiniętych o tyle ważne, że wraz ze zwiększaniem wielkości poszczególnych kanałów MTT, tj. wartości BIZ, importu high-tech 
i liczby patentów uzyskiwanych przez obcokrajowców, obserwować można jednoczesny wzrost poziomu innowacyjności gospodarki, tj. zwiększanie liczby patentów uzyskiwanych przez podmioty krajowe, zarówno w kraju, jak i za granicą, zwiększanie wielkości eksportu high-tech oraz wzrost wydatków na B+R. Wzrost wielkości MTT do krajów słabo rozwiniętych i wzrost poziomu ich innowacyjności wykazuje silną zależność [Ciborowski, 2016].

Można zatem wskazać szereg czynników wpływających na dynamikę procesu MTT i poziom innowacyjności krajów słabo rozwiniętych. Za kluczowe uznano proces globalizacji i będący jego efektem wzrost roli KTN, politykę gospodarczą, w tym szczególnie zagraniczną politykę ekonomiczną, oraz politykę innowacyjną oraz system instytucji formalnych.

Import dóbr high-tech uznać należy za główny kanał MTT do krajów słabo rozwiniętych. Świadczy to m.in. o zmianie struktury BIZ, polegającej na zmniejszeniu roli inwestycji w branże low-tech i mid-tech, i zwiększeniu znaczenia branż high-tech, wykorzystujących przy montażu przetworzonych produktów importowane komponenty. Proces ten stanowi najczęściej skutek fragmentaryzacji procesów produkcji w ramach KTN oraz zmian struktury dokonywanych przez nie inwestycji. Działania te, połączone z zastosowaniem odpowiednich instrumentów polityki gospodarczej, w tym szczególnie zagranicznej polityki ekonomicznej (np. ulgi podatkowe, strefy ekonomiczne, cła), zdeterminowały napływ BIZ i import high-tech. Wykorzystane instrumenty polityki innowacyjnej, w tym polityki naukowo-technologicznej, m.in. tworzenie podmiotów wsparcia innowacyjności, wzmocnienie międzynarodowych powiązań naukowych, zwiększenie finansowania sektora $B+R$, wpływają na tempo absorpcji zagranicznych technologii, a także działalność innowacyjną przedsiębiorstw w krajach słabo rozwiniętych.

\section{Podsumowanie}

Kraje rozwijające się zaliczane są do grupy krajów zdolnych do adaptacji technologii. Zmusza to je do koegzystencji z podmiotami zagranicznymi na tle technologii wytwarzania produktów reprezentujących odmienne poziomy zaawansowania technologicznego. Istniejące luki technologiczne wzmagają konkurencję rynkową oraz tworzą zachętę do wykorzystania przewag technologicznych przez wiodące firmy krajów słabo rozwiniętych. To z kolei dopinguje do imitowania procesów innowacyjnych i międzynarodowego transferu technologii. Sytuacja gospodarcza krajów słabo rozwiniętych nie pozwala na utrzymywanie zdolności innowacyjnych i często uniemożliwia wykorzystanie międzynarodowego transferu technologii. 
Procesy globalizacyjne zwiększają dostęp krajów słabo rozwiniętych do nowych technologii, wymaga to jednak coraz większego zakresu otwartości. Potrzebne są więc rozwiązania strukturalne i instytucjonalne dotyczące możliwości wspierania rozwoju innowacyjności, co wpłynie dodatnio również na tempo rozwoju gospodarczego oraz pozycję konkurencyjną. Czynnikiem decydującym wydaje się tworzenie rozwiązań na rzecz międzynarodowego transferu technologii.

\section{Bibliografia}

Arrow J.K., 1962, Economic Welfare and the Allocation of Resources for Invention, [w:] The Rate and The Directions of Inventive Activity. Economic and Social Factors, NBER, Princeton Press.

Bell M., Pavitt K., 1993, Technological Accumulation and Industrial Growth. Contrasts between Developed and Developing Countries, Industrial and Corporate Change, no. 2.

Boyer R., Drache D. (eds.), 1996, States against Markets, Routledge, New York.

Bozeman B., 2000, Technology transfer and public policy. A review of research and theory, Research Policy, no. 29.

Ciborowski R., 2016, Międzynarodowy transfer technologii a innowacyjność krajów Europy Środkowo-Wschodniej, PTE, Białystok.

Flaherty M.T., 1986, Coordinating International Manufacturing and Technology, [w:] Competition in Global Industries, ed. M.E. Porter, Boston Harvard Business School Press.

Foray D., 2007, Enriching the Indicator Base for the Economics of Knowledge, [w:] Science, Technology and Innovation Indicators in a Changing World. Responding to Policy Needs, OECD, Paris, http://213.253.134.43/oecd/pdfs/browseit/9207121E.PDF [dostęp: 20.03.2013].

Gu S., Steinmueller E., 1996, China's national innovation system approach to participation in information technology. The innovation recombination of technology capability, INTECH, Maastricht.

Hobday M., 1995, Innovation in East Asia. The challenge to Japan, Edward Elgar, Aldershot.

Hoekman B.M., Maskus K.E., Saggi K., 2005, Transfer of Technology to Developing Countries. Unilateral and Multilateral Policy Options, World Development, vol. 33, no. 10.

Jindra B., 2006, The Theoretical Framework. FDI and Technology Transfer, [w:] Technology Transfer via Foreign Direct Investment in Central and Eastern Europe, ed. J. Stephan, Palgrave Macmillan, New York.

Jun-Choi H., 2009, Technology Transfer Issues and a New Technology Transfer Model, The Journal of Technology Studies, vol. 35, issue 1.

Keller W., 1999, How Trade Patterns and Technology Flows Affect Productivity Growth, NBER Working Papers, no. 6990.

Mansfield E., 1995, Innovation, Technology and the Economy, Edward Elgar, Aldershot.

Mansfield E., 2002, Podstawy makroekonomii, AW Placet, Warszawa.

Misala J., 2003, Wspótczesne teorie wymiany międzynarodowej i zagranicznej polityki ekonomicznej, Szkoła Główna Handlowa, Warszawa.

Nelson R., 1991, Why Do Firms Differ and How Does It Matter?, Strategic Management Journal, no. 12.

Osman-Gani A.M., 1999, International technology transfer for competitive advantage. A conceptual analysis of the role of HRD, Competitiveness Review. An International Business Journal Incorporating Journal of Global Competitiveness, vol. 9, no. 1. 
Ozawa T., 1992, Foreign direct investment and economic development, Transnational Corporations, no. 1.

Poznańska K. (red.), 2001, Sfera badawczo-rozwojowa i przedsiębiorstwa w dziatalności innowacyjnej. Praca zbiorowa, Instytut Funkcjonowania Gospodarki Narodowej SGH, Warszawa.

Radosevic S., 1999, International technology transfer and catch-up in economic development, Edward Elgar, Northampton.

Ramanathan K., 2001, E-strategies for Technological Capability Development, Management of Engineering and Technology, vol. 1.

Shashikant S., Khor M., 2013, Intellectual Property and Technology Transfer Issues in the Context of Climate Change, http://www.twnside.org.sg/title2/IPR/pdf/ipr14.pdf [dostęp: 8.11.2013].

Souder W.E., Nashar A.S., 1990, A guide to the best technology-transfer practices, The Journal of Technology Transfer, vol. 15.

Stark D., 1996, Recombinant property in eastern European capitalism, American Journal of Sociology, vol. 10, no. 4.

Steenhuis H.-J., Bruijn de E.J., 2005, International Technology Transfer. Building Theory from a Multiple Case-Study in the Aircraft Industry, http://doc.utwente.nl/73596/1/international.pdf [dostęp: 20.01.2014].

UNIDO, 2003, Negocjacje w transferze technologii.

Utterback J.M., 1994, Mastering the dynamics of innovation, Harvard Business School, Boston.

Weresa M., 2012, Systemy innowacyjne we wspótczesnej gospodarce światowej, Wydawnictwo Naukowe PWN, Warszawa.

R. Ciborowski (- r.ciborowski@uwb.edu.pl

Wydział Ekonomii i Zarządzania, Uniwersytet w Białymstoku, ul. Warszawska 63, 15-062 Białystok, Polska 